\title{
Vesta Sarkhosh Curtis. "From Mithradat I (c. 171-138 BCE) to Mithradat II (c. 122/1-91 BCE): The Formation of Arsacid Parthian Iconography"
}

\section{Leonardo Gregoratti}

\section{(2) OpenEdition}

\section{Journals}

Electronic version

URL: https://journals.openedition.org/abstractairanica/53339

DOI: 10.4000/abstractairanica.53339

ISSN: 1961-960X

Publisher:

CNRS (UMR 7528 Mondes iraniens et indiens), Éditions de l'IFRI

\section{Electronic reference}

Leonardo Gregoratti, "Vesta Sarkhosh Curtis. "From Mithradat I (c. 171-138 BCE) to Mithradat II (c. 122/1-91 BCE): The Formation of Arsacid Parthian Iconography"', Abstracta Iranica [Online], Volume 42-43 | 2021, document 60, Online since 30 December 2021, connection on 23 December 2022. URL http://journals.openedition.org/abstractairanica/53339 ; DOI: https://doi.org/10.4000/ abstractairanica.53339

This text was automatically generated on 23 December 2022.

All rights reserved 
Vesta Sarkhosh Curtis. "From Mithradat I (c. 171-138 BCE) to Mithradat II (c. 122/1-91 BCE): The Formation of Arsacid Parthian Iconography"

Leonardo Gregoratti 


\section{REFERENCES}

Vesta Sarkhosh Curtis. "From Mithradat I (c. 171-138 BCE) to Mithradat II (c. 122/1-91

BCE): The Formation of Arsacid Parthian Iconography" in Yousef Moradi (ed.).

AfarinNameh: Essays on the Archaeology of Iran in Honour of Mehdi Rahbar. Tehran: The

Research Institute of Cultural Heritage and Tourism (RICHT), 2019, p. 25-30.

In this paper, the author deals with the transformations the Parthian official coin iconography underwent between Mithridates I and Mithridates II (171-91 BC). After Mithridates' conquest of Media and Mesopotamia, the soft hat of the early Arsacids was substituted by a diadem, the symbol of Hellenistic kingship. Mithridates I adopted the title of philhellene to underline his alliance with his Greek subjects and introduced Iranic elements like the full beard. The title "king of kings" was introduced under that king, but only under his successor Mithridates II, it was adopted permanently. Again, Mithridates I introduced the reverse motifs of the standing Heracles/Verethagna and the seated archer (Arsakes I). With Mithridates II, new oriental elements appeared, especially in the elaborate decoration of the king's and the archer's dress. The jewelled and diademed tiara appears under his rule along with moon crescents and the new title of "Great king of kings".

\section{AUTHORS}

\section{LEONARDO GREGORATTI}

Durham University 